\title{
NiUE'S RELATIONSHIP OF FREE ASSOCIATION WITH NEW ZEALAND
}

\author{
A Quentin-Baxter
}

\section{NIUE'S CONSTITUTIONAL STATUS}

For not quite twelve years, Niue has been a self-governing state in a relationship of free association with New Zealand. The terms "self-governing" and "free association" have been used in different parts of the world to describe a variety of constitutional arrangements and formal links between states. In themselves, they throw little light on the status of Niue under its own Constitution, or on the nature of the arrangements which link Niue and New Zealand.

Self-government in Niue and the relationship of free association with New Zealand follow a pattern earlier established in respect of the Cook Islands. The details were tailored to Niue's special needs. The concept of self-government in free association as it applies to New Zealand's two associated states is both unique and evolutionary. It is also sufficiently flexible to allow each of the associated states the freedom to work out, in agreement with New Zealand, the type of relationship which suits it best.

The foundation for Niue's self -government in free association with New Zealand is an Act of the New Zealand Parliament passed at the request of the people of Niue and adopted by them in a referendum constituting an act of self-determination. It has the force of law in each country, and represents also the most solemn compact between them.

Under the Niue Constitution Act 1974 Niue is to be self-governing. The scheduled Constitution is to be the supreme law of Niue. It confers plenary powers on the Government of Niue, and no act of government affecting Niue is outside that Government's responsibilities. By enacting these provisions, the New Zealand Parliament irrevocably put it beyond its own powers to make laws for Niue. No organ of the executive or judicial branches of the New Zealand Government has any authority in Niue unless that authority is given to it by the Constitution or other law. These essential features of Niue's selfgovernment are the fixed boundaries within which the relationship of free association must be made to work.

In comparison with the detail of the Constitution, the terms of the free association, as set out in the Niue Constitution Act, are sketchy. The people of Niue are to remain New 
Zealand citizens. The Government of New Zealand's existing responsibilities for the external affairs and defence of Niue are not to be affected. A continuing responsibility is laid upon the Government of New Zealand to provide necessary economic and administrative assistance to Niue.

The machinery for implementing the relationship gives a glimpse of its nature. The New Zealand Government's responsibilities are to be carried out after consultation between the Prime Minister of New Zealand and the Premier of Niue. As with other aspects of the relationship calling for positive cooperation between New Zealand and Niue, the discharge of the New Zealand Government's responsibilities requires an accommodation between the policies of the two Governments. As a visible symbol of the relationship and a means of giving it content, there is to be a representative of the Government of New Zealand stationed in Niue.

As these arrangements are the foundation upon which Niue's self-government was built, they have a constitutional as well as a contractual character. They are capable of being modified by agreement between the parties, but no Government in Niue may take this step unless it has been approved by a two-thirds majority both in the Niue Assembly and in a referendum.

\section{A Reconciling Free Association and Self-Government}

The form of self-government in free association developed by New Zealand and its associated states was recognised by the United Nations as bringing to an end the former colonial relationship. It was not seen as a stepping stone to independence, but as a status of indefinite duration, though an associated state is free to terminate the relationship at any time if its people so decide in a further act of self-determination. Termination by New Zealand, or departure from the terms of the free association, effected unilaterally, would be a breach of the Government's obligations, unless, like a divorce, these events marked the irretrievable breakdown of the relationship.

As an alternative to independence, or to integration with an existing state, selfgovernment in free association cuts across some of the concepts which are basic to the idea of the nation state. How is the political autonomy of the associated state to be reconciled with a shared citizenship, with the notion that New Zealand and its associated states are for some - but not all - purposes a single entity internationally, and, at least in the case of Niue, with a permanent need to supplement its own resources with financial assistance from New Zealand?

The solutions have to be innovative, they have to reflect the fact that free association is a relationship between governments but cannot work without an underlying commitment to shared values. The status cannot be assimilated either to independence or to integration. It 
involves a synthesis of some attributes of each. For each of the associated states, the mix must reflect its own priorities and capacities, as well as New Zealand's legitimate concerns.

With the direction and pace of evolution so far set mainly by the Cook Islands, more specific content has been given to the relationship of free association at times when that country has been most conscious of its separate identity. For Niue, the emphasis is not on drawing further away from New Zealand but on drawing closer. There is nothing to prevent Niue's relationship from developing in this different direction, so far as is compatible with self-government.

The people of Niue are justly proud of their demonstrated ability to govern themselves under their Constitution. Their self-confidence and their sense of national identity have grown immeasurably in the period of self-government. The population loss, the failure of agricultural projects and some criticism of the Government for not responding sufficiently to the needs of people outside Government circles have not stood in the way of an almost universal determination to maintain Niue's present constitutional status.

There is, however, a widespread sense of disappointment that, in tangible and intangible ways, the "special relationship" with New Zealand has been, as one speaker put it, "not so special" in practice. The purpose of this Review is to take a fresh look at all the elements in the relationship, and to suggest ways in which it may be made to work better; but this must be done without detracting from the reality of self-government.

\section{THE GUARANTEES ACCOMPANYING FREE ASSOCIATION IN PRINCIPLE AND IN PRACTICE}

The people of Niue were promised that they could have self-government without losing their right to New Zealand citizenship or to continuing economic and administrative assistance from the Government of New Zealand. Without these guarantees, it is inconceivable that they would have chosen to become self-governing. At the time, the modest hopes for a strengthened economy in the future were not seen as lessening Niue's heavy and continuing dependence on New Zealand's financial aid. It was recognised to be an irreversible consequence of Niue's past administration by New Zealand that every Niuean was influenced by New Zealand values, and was accustomed to living standards that the resources of the island could not sustain. Many Niueans had chosen to use their labour and skills in New Zealand, making a significant contribution to the New Zealand economy and often continuing to support members of their families in Niue. For this reason the retention of New Zealand citizenship was as important to the people of Niue as the guarantee of economic support in Niue itself.

When the people of Niue chose to become self-governing in free asociation with New Zealand, they could reasonably have expected that the relationship would have been built around these guarantees and the realities which had called them into being. It is fair to say 
that this has not happened. In Procrustean fashion, the guarantee of economic and administrative assistance has been made to fit into the existing overseas aid programme. To the extent that they have been focussed upon at all, the citizenship rights of the Niueans, carrying with them access to a New Zealand standard of living, have been regarded as a negative factor. The resulting dependence upon New Zealand's financial assistance for recurring purposes, usually described as the need for budgetary aid, has been seen as frustrating the proper objectives of overseas aid by requiring it to be diverted from development projects, reducing the share available for New Zealand's other aid partners, producing an embarrassing imbalance in the allocation of aid on a per capita basis, and, above all, preventing progress towards the goal of economic self-sufficiency. These perceptions were an inevitable consequence of the assumption in 1975 that the regular aid policies and procedures adopted by the Ministry of Foreign Affairs should, if possible, be applied to Niue.

Within the straitjacket of this preconception, those engaged in the administration of aid have done their best to meet sympathetically Niue's requests, made almost annually, for special treatment to take care of some shortfall in projected revenue or some unexpected increase in expenditure. They have also realised to some extent that, under the terms of free association, Niue had a claim to preferential treatment which justified a departure from the regular aid programme in order to permit some long term planning.

If the fulfilment of New Zealand's responsibilities to Niue is to be measured in terms of the proportion of New Zealand's overseas aid budget and the monetary value of the aid that have been devoted to Niue, that country has been treated generously in comparison with others. In both countries, however, there is a deepening awareness that this onedimensional portrayal of the practical operation of the relationship of free association is not the whole picture. It is necessary to widen the focus.

\section{A The Nature of the Relationship of Free Association}

On the whole, New Zealand's dealings with its associated states have been conducted with the same pragmatism which characterised New Zealand's own transformation from colony to self-governing Dominion and eventually to full nationhood. There has been a need to rationalise the exercise of responsibilities only in one or two areas.

The first relates to the conduct of the external relations of the associated states, especially when the New Zealand Government has been entering into treaties by which they will be bound, or the associated states have themselves have wished to become parties to a treaty. There has also been a need to devise a means by which the Cook Islands Government could advise the Queen on the appointment of the Representative of the Head of State. Simple as the prescription sounds, it has been hard for both sides to accept that, if the 
relationship is to work well in these spheres, each partner Government should act only after taking due account of any interests of the other Government which may be affected.

The second area relates to the New Zealand Government's concern that the system of government applying to any of its citizens should be democratic, respecting the rights of the individual and the rule of law. The Governments of New Zealand and of the Cook Islands have recognised that it is unusual for a state to extend its citizenship to people living in areas beyond the reach of its own laws. They have acknowledged that the bond of citizenship does entail a degree of New Zealand involvement in Cook Islands affairs. In particular, it creates an expectation that the Cook Islands will uphold, in its laws and policies, a standard of values generally acceptable to New Zealanders. The scale of New Zealand's response to the Cook Islands' material needs is to be seen as a reflection of New Zealand's determination to safeguard the values on which its citizenship is based, while understanding the Cook Islands' natural desire to lead a life of its own.

The principles sometimes rather painfully hammered out in these contexts have had greater practical application to the Cook Islands than to Niue, and they concern the limits of separate action, not the need for cooperative effort. The paradox is that the Cook Islands and New Zealand, often wanting to go their separate ways, have had to accommodate themselves to the fact that they are not in the relationship of two independent states. Niue, wishing to enjoy a full measure of the guaranteed right to necessary economic and administrative assistance, has had to fight against the idea that it should be treated as though it had become independent.

It is important to understand, therefore, that the relationship of free association between New Zealand and Niue has both quantitative and qualitative elements. The quantitative element is represented by the specific rights and responsibilities in respect of citizenship, defence and foreign affairs, and economic and administrative assistance set out in the Niue Constitution Act. In intensity and character, these go far beyond any obligations which now govern, expressly or impliedly, the relationship between New Zealand and any fellow member of the Commonwealth or foreign state, however close the ties.

The qualitative element is usually described as a commitment to shared values, embodied most graphically in the undivided citizenship. This commitment is capable of transcending both self-interest and the normal boundary between matters which are of legitimate concern in relations between states and those which involve a state's internal affairs. It is a measure, first of all, of what is required to honour the specific obligations referred to above. It also means that no concern of one partner may be regarded as outside the duty of the other to give a considered response. Each Government has the constitutional authority to implement its own policies, but this is not a reason for refusing to recognise that those policies may have implications for the other. 
In other words, the concept of free association is not restricted to the performance of the specific obligations for which it provides. It has a pervasive character, colouring and informing the whole of the relationship. The constitutional autonomy of each of the partner governments must, of course, be fully respected. Solutions cannot be imposed, they must be negotiated. In the nature of things, negotiating strength can seldom if ever be equal; but there is on each side a notion of powers to be used at times for the benefit of the other partner, or freely employed in identifying and pursuing their common interests.

\section{B The Guarantee of Economic and Administrative Assistance and the Guarantee of Citizenship}

Because the assurance of continued economic support from New Zealand was just as important to the people of Niue as the retention of their New Zealand citizenship, the Niue Constitution Act 1974, in contrast to the Cook Islands Constitution Act 1964 which is silent on the subject, provides in section 7: "It shall be a continuing responsibility of the Government of New Zealand to provide necessary economic and administrative assistance to Niue".

At the time there was some surprise among members of Parliament that the people of Niue should have felt that this guarantee needed to be spelt out. They could, it was suggested, have taken it for granted that New Zealand would not regard self-government as a reason for cutting off the economic and administrative assistance it had provided for many years. There was an awareness among members that the economic resources of Niue appeared to be slender. The people could not feel that, unaided, they were viable as a country. Whatever Government was in power, New Zealand would continue to give them economic and administrative assistance, whether or not that provision was written into the law.

Section 5 of the Act made it clear that self-government would not deprive the people of Niue of their New Zealand citizenship. Although cast in the same negative form as the corresponding provision in section 6 of the Cook Islands Constitution Act, the guarantee was seen in positive terms. As the Minister in charge of the Bill put it, "Niueans are very proud of being New Zealand citizens, and in their eyes this bond is sacrosanct".

Another member addressed himself to the many people in New Zealand who might wonder why Parliament was showing such concern for a community that had fewer people than Westport. The grant of self-government and the guarantees that went with it were not, he said, a symbolic gesture to fall in with the wishes of a small group of people in Niue or to conform to some sort of pressure from the United Nations; "it is a recognition by this Parliament that the people of Niue have their own individual cultural heritage of which they themselves are the best guardians. We are assisting them to pursue the development of that culture in the way that is best suited to them". 
The question now is how the guarantees in the Niue Constitution Act, and the spirit in which they were given, are to be made the basis of a programme for future economic and administrative assistance to Niue within the framework of the relationship of free association. It is not the task of the Review Group to preempt the decisions on priorities which can be made only by Governments, but it can suggest the issues which arise and the way in which they might be approached.

\section{The Principles Which Should Govern the Provision of Necessary Economic and Administrative Assistance in the Future}

\section{Who decides what is "necessary economic and administrative assistance"?}

The avowed aim of the mission from the Ministry of Foreign Affairs which visited Niue in 1975 to discuss the basis for the future provision of financial assistance to Niue was to contain budgetary support in order to allow the maximum amount for development. The mission acknowledged, however, that to prevent large-scale migration, reasonable salary levels and a good standard of living were required in Niue. The reason for emphasising development was expressed in terms of a desire to conform with New Zealand's policies in relation to other aid partners, comprising at that time mainly the small independent states of the South Pacific. (The Cook Islands, and Tokelau were brought under the External Aid Division's umbrella only at the same time as Niue.)

The emphasis on development seems to have accorded well enough with the priorities of the Niue Government at the time, though there is no record of any discussion on this question. It seems likely that Niue for its own purposes, and New Zealand for the purpose of its overseas aid programme, each saw internally sustained development as the measure of a society's well-being and the basis of planning for the future.

Recently, the authors of a study by the Victoria University Institute of Policy Studies on New Zealand's relations with its small island neighbours, commissioned by the Ministry of Foreign Affairs, have suggested that "development" is not necessarily the key to the long term survival of society in these microstates. If this view were to be accepted, New Zealand's aid policies would presumably be modified accordingly. New Zealand's aid partners, including Niue, would then be presented with the need to conform to a different order of priorities for the allocation of aid.

This past history and possible scenario for the future demonstrate that, for Niue, there is an important preliminary issue. There is no question of Niue being offered overseas aid by New Zealand on a "take it or leave it" basis. In the most solemn way they could, New Zealand and Niue have recorded in the Niue Constitution Act that the "necessary economic and administrative assistance" to be provided by the New Zealand Government comes to Niue as of right. 
In 1979, the Government of Niue invoked this right. This led to what was described by the Ministry as a "compromise" under which the terms of aid for the period of Niue's Development Plan 1980-85 were redefined. There can be no assumption, however, that, even with modifications, an "aid" policy, dealing with what is essentially the voluntary provision of funds to assist other independent states in the way in which the New Zealand authorities think they ought to be assisted, will ever be a suitable way of giving effect to the obligation assumed by the New Zealand Government towards the people of Niue.

For this reason, and for others going to the heart of their self-confidence and self-respect, even the term "aid", with its connotations of charity as well as of failure on the part of the recipients to achieve success through their own efforts, is disliked by Niueans. There is no reason to depart from the language of section 7 which refers to the "continuing responsibility of the Government of New Zealand to provide necessary economic and administrative assistance". That obligation can then be seen in its proper setting, and criteria bearing on its content and implementation can be identified.

Unfortunately, there is no ready answer to the question posed above, foreseeing the differences that may arise between the two Governments on the policy objectives to be served by the provision of assistance, the purposes for which it will be deployed, the amounts, in cash and kind, which are "necessary", and the extent to which there should be accountability for the way in which the resources provided are actually used. Neither Government has the absolute right to insist that its view must prevail. There are, however, two sources of principle.

In the first place, Section 7 of the Niue Constitution Act records Parliament's recognition that the democratically elected legislature in New Zealand will raise revenue from its citizens in order that it may be expended for the benefit of fellow-citizens, under the control of the democratically elected legislature in Niue. It is both a strength and a weakness of each Government's position that one of them controls the provision of funds and the other controls their spending. The assumption is that when one partner has to rely on the other to do things which would normally be within its own constitutional powers, "shared values" will compensate for the loss of controlling authority.

The second part of the equation is the brief edict in section 3 : "Niue shall be selfgoverning". The whole purpose of self-government was to give the people of Niue the power to make the decisions about the use of the resources available to them. The New Zealand Government may not use its power of the purse in a way that is inconsistent with that concept.

Section 8 of the Act lays down the modalities to be followed. The first step is consultation between the Prime Minister and the Premier, with a view to resolving any differences of approach between them; but the duty after that to give effect to the provisions 
of section 7 "in accordance with the policies of their respective Governments" makes it clear that the obligation to provide assistance and the right to use it remain, even in the absence of full agreement.

Secondly, there is a stipulation that any provision needing to be made in the law of Niue to carry out the policies of the two Governments shall be made only in the manner prescribed in the Constitution. This is a reminder that, even if the Government of New Zealand is the paymaster, the provisions of the Constitution concerning the control of public revenue and expenditure by the Niue Assembly still apply. As a matter of law, each Government is bound by the duty of conformity with those requirements.

Finally, the reference to the aspects of the relationship between New Zealand and Niue "which may from time to time call for positive co-operation between New Zealand and Niue" is a significant pointer to the way in which the relationship as a whole must be implemented. The notion that Niue's self-government requires a stand-off attitude on New Zealand's part until the Niue Government's policies and priorities with regard to both recurring and capital expenditure have been settled is a mistaken one, because it can only pave the way for eventual confrontation. Certainly, Niue's self-government must always be respected, and the relationship must always operate on a government to government basis, but there is every indication that its essentially co-operative nature has not been fully appreciated.

In particular, the New Zealand Representative in Niue has been under-utilised as a means of reaching common ground about the purposes, kinds and amounts of economic assistance that are 'necessary' to Niue. In addition, the responsibility to provide necessary administrative assistance, up till now a neglected aspect of the relationship at the conceptual level, may also be a means of providing expert help in identifying needs and how best to meet them, so long as it does not involve individuals in conflicts of loyalties. The question of the machinery for "positive co-operation" is secondary, however, to its function as one of the driving forces of the relationship.

\section{What is the meaning of "necessary" economic and administrative assistance?}

In section 7 of the Niue Constitution Act, the reference to 'necessary' economic and administrative assistance is the vehicle for taking into account all the relevant factors when making decisions about the objects, purposes, kinds, and amounts of the assistance that the New Zealand Government should provide to Niue. In order to decide what is "necessary", the policies and priorities of the two Governments have to be brought to bear, through the decision-making process already described.

The difficult question is how far the outcome of this process is pre-determined by reference to the word "necessary". In accordance with the basic principle of statutory interpretation that every word in a statute must be assigned a meaning, the duty to provide "necessary" assistance clearly implies that the assistance is required for a purpose, and also 
that a value judgment must be made as to what is needed to carry out this purpose. In the context, the purpose must be the maintenance of society in Niue, but the question of what is needed for this purpose is not prejudged in terms of the standards of living to which the people of Niue may aspire or the economic and social policy which the Government of Niue may follow in order to contribute to what is described in Article 69(3)(c) of the Constitution as "the general well-being of Niue".

There are many things, in this and other articles of the Constitution, and in the arrangements for free association, that clearly have a bearing on these prior questions. Foremost among them is the New Zealand citizenship of the people of Niue with all its implications and consequences, direct and indirect. The shared citizenship is not relevant only for the reason that it gives the people of Niue the alternative of choosing to live in New Zealand. Its prime importance is the standard it sets for the people of Niue while they are living in Niue.

As has been seen, the Government of New Zealand has laid down the principle that it will always have a concern for the civil and political rights of the people of its associated states and for their material welfare, simply because it is determined to safeguard the values on which New Zealand citizenship is based. It does not follow that the conditions of life in Niue must somehow be made the same, so far as money could make them, as the conditions of life in New Zealand; but a comparison of both the benefits and the burdens of living in one country or the other will often be relevant, and the differences in standard of living must always be kept within reasonable bounds. That question needs to be returned to in greater depth.

What is the meaning of a "continuing" responsibility to give necessary economic and administrative assistance?

Like the word "necessary", the word "continuing" must have a meaning. It cannot have been put there simply to establish that, even after Niue became self-governing, it would continue to have the right to assistance. That would have been clear without it. Although it seems not to have been discussed at the time, perhaps because it seemed so obvious, the "continuing" responsibility of the Government of New Zealand means that it is a responsibility which cannot be discharged by a one-off contribution, or contributions for a limited period, or only so long as certain conditions are complied with. It has special relevance in the context of worries about the per capita cost of assistance to Niue. Although the question of relative costs and benefits must always be relevant in deciding what assistance is necessary, there can be no a priori cut-off point by reference to such a criterion. "Continuing" means continuing so long as there are people living in Niue under a constitution for self-government and in a relationship of free association with New Zealand. 